\title{
The role of CD26 and CD40 expression in therapeutic response - experimental study in oral cancer lines
}

\author{
Joana PN Batista ${ }^{1,2^{*}}$, Sílvia S Neves ${ }^{2,3}$, A Cristina Gonçalves ${ }^{2,3}$, Vera Alves ${ }^{4}$, Ana Sarmento-Ribeiro ${ }^{2,3,5}$, \\ Marília Dourado ${ }^{2,6}$
}

From 16th International Charles Heidelberger Symposium on Cancer Research

Coimbra, Portugal. 26-28 September 2010

Oral cancer $(\mathrm{OC})$ is one of the 10 most diagnosed cancers in the world. It is aggressive and difficult to treat. Despite the achieved therapeutic advances, the 5 year survival rate has not changed in the past decade. Understanding the basic molecular pathogenesis of OC may give new opportunities for future treatments. Regulators of the immune system such as CD40 [1]. and CD26 [2] are believed to be involved in carcinogenesis besides immunologic anti-tumour defence. The aim of this study was to evaluate the influence of CD26/DPPIV and CD40/CD40L cell expression in two OC cell lines and treatment response.

For this two human OC cell lines BICR10 (in situ) and HSC3 (metastatic) were incubated with cisplatin in different concentrations. Cell morphology was evaluated by light microscopy and cell viability was estimated by alamar blue test. Cell death CD26 and CD40/CD40L expression was evaluated by flow cytometry and DPPIV by luminescent assay.

Preliminary results show that BICR10 has higher CD26/DPPIV levels and lower CD40/CD40L expression than HSC3. However, after treatment with cisplatin expression of CD40/CD40L and DPPIV increases in both cell lines that could be related with apoptosis detected by morphology and cytometry.

Our results suggest that CD40/CD40L and CD26/ DPPIV can be involved in OC development and drug response and could constitute a new molecular target to cancer diagnosis/prognosis and treatment.

\footnotetext{
* Correspondence: juananevesbatista@gmail.com

'Department of Life Sciences, Faculty of Sciences and Technology, University of Coimbra, Coimbra, Portugal

Full list of author information is available at the end of the article
}

\section{Author details}

${ }^{1}$ Department of Life Sciences, Faculty of Sciences and Technology, University of Coimbra, Coimbra, Portugal. ${ }^{2}$ CIMAGO, Faculty of Medicine, University of Coimbra, Coimbra, Portugal Portugal. ${ }^{3}$ Applied Molecular Biology/ Biochemistry Institute, Faculty of Medicine, University of Coimbra, Coimbra, Portugal. ${ }^{4}$ Institute of Immunology, Faculty of Medicine, University of Coimbra, Coimbra, Portugal. ${ }^{5}$ Haematology, Faculty of Medicine, University of Coimbra, Coimbra, Portugal.. ' $P$ Physiopathology of Dental Medicine, Faculty of Medicine, University of Coimbra, Coimbra, Portugal.

Published: 24 September 2010

\section{References}

1. Vonderheide $\mathrm{RH}:$ Prospect of targeting the $\mathrm{CD} 40$ pathway for cancer therapy. Clin Cancer Res 2007, 13:1083-1088.

2. Havre PA, Abe M, Urasali Y, Ohnuma K, Morimoto C, Dang NH: The role of CD26/dipeptidil peptidase IV in cancer. Front Biosci 2008, 13:1634-1645.

doi:10.1158/1078-0432.CCR-06-1893

Cite this article as: Batista et al:: The role of CD26 and CD40 expression in therapeutic response - experimental study in oral cancer lines. $B M C$ Proceedings 2010 4(Suppl 2):P9.
Submit your next manuscript to BioMed Central and take full advantage of:

- Convenient online submission

- Thorough peer review

- No space constraints or color figure charges

- Immediate publication on acceptance

- Inclusion in PubMed, CAS, Scopus and Google Scholar

- Research which is freely available for redistribution

Submit your manuscript at www.biomedcentral.com/submit
C Biomed Central 